\title{
Contextual Teaching And Learning Assisted With School Environmental Media Affect The Science Knowledge Competency Of Grade IV Elementary School
}

\author{
Gst Ayu Md Okayanti \\ Pendidikan Guru Sekolah Dasar, Universitas Pendidikan Ganesha, Singaraja, Indonesia \\ e-mail: ayu.made.okayanti@undiksha.ac.id
}

DB.Kt. Ngr. Semara Putra

Pendidikan Guru Sekolah Dasar, Universitas Pendidikan Ganesha, Singaraja, Indonesia e-mail:semara.putra@undiksha.ac.id

\section{A R T I C L E I N F O \\ Article history: \\ 1 Agustus 2020 Received in revised form \\ 20 September 2020 \\ Accepted 10 November 2020 \\ Available online 20 \\ November 2020 \\ Kata Kunci: \\ CTL; Lingkungan; IPA \\ Keywords: \\ CTL, Snvironment, Science}

\begin{abstract}
A B S T R A K
Minimnya semangat belajar membuat nilai tahun sains siswa rendah, terbukti dengan rata-rata nilai pengetahuan sains siswa yang mendapatkan nilai di bawah Kriteria Ketuntasan Minimal. Penelitian ini bertujuan untuk mengetahui pengaruh yang signifikan pendekatan pembelajaran kontekstual berbantuan media lingkungan sekolah terhadap kompetensi pengetahuan IPA siswa kelas IV SD. Penelitian ini diklasifikasikan sebagai eksperimen semu dengan desain kelompok kontrol non-ekuivalen. Populasi dalam penelitian ini adalah seluruh siswa kelas IV yang berjumlah 482 siswa. Pengambilan sampel menggunakan teknik cluster random sampling. Kelompok sampel yang dipilih adalah kelas IVB sebanyak 33 siswa sebagai kelompok eksperimen dan sebanyak 31 siswa kelas IV sebagai kelompok kontrol. Alat pengumpulan data yang digunakan berupa tes kompetensi pengetahuan IPA. Data posttest. Analisis kompetensi pengetahuan IPA menggunakan uji-t dengan rumus polled variance. Nilai rata-rata posttest kelompok eksperimen adalah 82,42, dan nilai rata-rata post-test kelompok kontrol adalah 74,90. Analisis uji-t diperoleh thitung $=3,831$ dan pada taraf signifikansi 5\% dan $\mathrm{df}=62$ diperoleh ttabel $=2.000$. Karena thitung $>$ ttabel maka H0 ditolak (gagal diterima). Terkait hasil analisis dapat disimpulkan bahwa pendekatan pembelajaran
\end{abstract} kontekstual berbantuan media lingkungan sekolah berpengaruh signifikan terhadap kompetensi pengetahuan IPA siswa kelas IV SD.

\section{A B S T R A C T}

The lack of passionate learning makes students' science year low, as evidenced by the average score of students in science knowledge getting grades under the Minimum Completion Criteria. This study aimed to determine the significant influence of contextual teaching and learning approach assisted by school environment media on the competence of science knowledge of grade IV elementary students. This research was classified as pseudo experimentation using a non-equivalent control group design. The population was all grade IV students, with a total of 482 students. Sampling was using cluster random sampling technique. The sample group selected was grade IVB as many as 33 students as an experimental group and as many as 31 grade IV students as a control group. Data collection tools were used in the form of IPA knowledge competency tests. Posttest data. The science knowledge competency is analyzed using a t-test with polled variance formula. The experiment group's average post-test value was 82.42, and the average post-test value of the control group was 74.90. The t-test analysis obtained tcount $=3,831$ and at the level of significance $5 \%$ and $\mathrm{df}=62$ obtained ttable $=2,000$. Because tcount $>$ ttable then $\mathrm{H} 0$ is rejected (failed to accept). Related to the analysis results can be concluded contextual teaching and learning approach assisted by the school environment media significantly affects the competence of science knowledge grade IV elementary school students.

\section{Introduction}

Learning is the process of interaction of learners with educators, with lesson materials, delivery methods, learning strategies, and learning resources in a learning environment (Effendi-Hasibuan et al., 2020; Pane \& Dasopang, 2017). The learning process is an effort to make students learn; indeed, a situation is a learning event (event of learning) that is an effort to change students' behaviour (Juniasih et al., 2013; Kasanah et al., 2019). Behaviour changes can occur due to interactions between students and their environment. Learning plays an essential role in learning because, in learning, there are learning events and teaching events. Learning is a psychophysical activity caused by learning activities itself. Good learning is learning that there are teaching activities of teachers and learning activities of learners. Between teacher teaching activities and learner learning activities, this is often called learning interaction.

Yet, in reality, students' science knowledge competency is low because students are not passionate when studying in class (Agustino et al., 2016). The semester's final science test value on the average load still 
gets a score below the standard minimum completion criteria (Putri et al., 2018). The same is mentioned that students' general replay average is still far from the very good criteria (Suarnaya et al., 2015). The majority of elementary school students do not understand science material students find the material very difficult (Oviyana et al., 2015). The percentage of students who get grades above KKM is fairly low (Yuliana et al., 2015). Students, when learning, sit sweetly listening to information without being coloured by the learning experience so that the value of students' science knowledge is far from desired in KKM (Widya et al., 2015). This case is supported by the results of interviews with all students and teachers of grade IV SD Cluster Lt. Col. Gusti Ngurah Rai North Denpasar School Year 2019/2020 said students' value' science knowledge is still low. The result of the interview is that some students still get science knowledge value under the Minimum Completion Criteria, namely from the total number of students, namely as many as 482 students there are 146 students or $30 \%$ of students who get grades under the Minimum Completion Criteria. Students say that the content of science lesson material is less attractive. They tend to be passive in the classroom, often exhausted, and science material content is considered very difficult to understand, causing students to saturate following the learning. The material studied is very easy to forget because students only tend to memorize not doing hands-on practice about how they connect between theory and knowledge gained with real activities, while revealing the results of discussions in front of the class students are still many who are nervous and lack confidence. With the problems presented, there needs to be an effort to change the previous paradigm with the latest paradigm by designing a new learning atmosphere so that learning is more meaningful in the hearts of students and can grow the competence and knowledge owned by the students themselves.

The solution to improve the competence of science knowledge is to apply an approach during the learning process. Learning access needs to be bridged by an appropriate learning approach. The learning approach used is meaningful in students' hearts where the teaching materials are packed with related to the cases that exist in the student's daily life. Students receive a learning experience that is explicit and activates students' curiosity about science lessons. The learning approach in question is contextual teaching and learning approach with the help of school environment media. Very confident that the CTL approach is superior when practised in elementary school because it is very competent in providing efforts towards academic expertise by linking the theories studied with the real circumstances encountered by students, this will make it easier for students to remember material and long stored in the brain.

Contextual Teaching and Learning is a learning approach that focuses on sharing a meaningful experience with students through activities connecting learning activities to the outside environment around the classroom (Trianto, 2010). The opinion is also supported by the idea of (Shoimin, 2014) CTL oriented towards students learning to link between the material studied and students' daily activities by implying seven main components: constructivist, wonder, get information, discussion, demonstration, evaluation. Please note that CTL can also increase students' knowledge fully because students are active and independent in finding learning materials by sending and absorbing knowledge through group discussions. The learning process will run naturally because it is given a hands-on learning experience such as in the real world. Learning becomes meaningful and impressed long in the student's memory and accelerates students' understanding of the material's content with experience in learning. One of the most efficient outside environments to help students provide a direct learning experience is the school environment. Which is the school environment is the closest environment for students in doing daily activities. The environment includes all elements of any kind in the world that can affect human behaviour (Idrus \& Novia, 2018; Julianti et al., 2018; Marini \& Hamidah, 2014). Also supported by , utilizing the learning environment will realize a different learning nuance from the first.

Some of the research that contextual the results of this study include research conducted by Luh (Anjani et al., 2020) stated that contextual teaching and learning model assisted by concrete media affects the competence of science knowledge. IPA knowledge competency data is collected using the usual multiple-choice objective test with a valid question count of 33 items. Analysis based on the results obtained data $t_{\text {count }}=7,542>$ $\mathrm{t}_{\text {table }}=2,000$ at the level of significance $5 \%$ with $\mathrm{dk}=61$ so that there are significant differences in the competence of science knowledge group taught with contextual teaching and learning model concrete media assistance with students who are studied with conventional learning models.

In order to test the competency of students' science knowledge, there are many things that students can get in the learning process to influence the improvement of science knowledge competency. Then it needs to be followed up by conducting a research entitled "The Influence of Contextual Teaching and Learning Approach assisted by School Environment Media on Science Knowledge Competency of Grade-IV Students of SD Cluster Lt. Col. I Gusti Ngurah Rai North Denpasar School Year 2019/2020".

\section{Method}

This research was conducted in class IV of Lt. Col. I Gusti Ngurah Rai North Denpasar School Year 2019/2020. This study aimed to determine the competence of science knowledge between students who were 
taught with a Contextual Teaching and Learning Approach assisted by School Environment Media and groups of students who were taught with conventional learning. The research design used in this study is Non-equivalent Control GroupDesign. This study's design did not randomly select participants to be included in the experimental or control group but had two groups where both groups received different treatment but both received pretests and post-tests.

The population is defined as the generalization area of the research results (Sugiyono, 2012). The population is a set of individuals with the same characteristics and can then be sorted back into research materials. Based on the exposure, it can be concluded that a population is a group of similar objects living in an area to be examined by researchers and establish assumptions. This study's population was the entire fourth grade of SD Cluster Lt. Col. I Gusti Ngurah Rai North Denpasar School Year 2019/2020. The total number of students in the study population was 482 people, consisting of 14 classes evenly in 6 elementary schools. However, this study only researched public elementary schools because private elementary schools used different curricula and excellent and non-superior classes.

Data collection was required in a way called the data collection method. The test method is one of the ways used to collect data in this study. According to Agung (2014) test method is a way to obtain data in the form of tasks done by a person and then measured using a score. The instrument used to collect science knowledge competency data was an objective test in regular multiple-choice.

The hypothesis test conducted in this study uses t-test analysis. Before the t-test analysis, it must first meet the prerequisite test of analysis, namely the test of normality of data distribution and homogeneity of variance.

\section{Result and Discussion}

\section{Results}

The data analyzed in this study were data on students' science knowledge competencies that taught with Contextual Teaching and Learning approaches assisted by School Environment Media in experimental classes and students who were taught with conventional learning in control classes. Recapitulation of the calculation of research data on students' science knowledge competencies can be seen in table 1 - summary of t-Test Calculation Results. A data normality test was conducted to determine data distribution from the normal distribution of research results. The normality test of students' SCIENCE knowledge competency data using Kolmogorov-Smirnov analysis formula at a rate of 5\% significance and degree of freedom (df) $=\mathrm{n}-1$. For experiment classes, the analysis results obtained a maximum value of $\left|F_{T}-F_{S}\right|=0.09$. Then converted to KS table price with $\mathrm{df}=32$ and significance level $5 \%$, which obtained the price of $\mathrm{KS}_{\text {table }}=0.23$. Because the maximum value of $\left|\mathrm{F}_{\mathrm{T}}-\mathrm{F}_{\mathrm{S}}\right|=0.09<\mathrm{KS}_{\text {table }}=0.23$ then $\mathrm{H}_{0}$ received (failed to reject). This means the distribution of the science knowledge competency data of normally distributed experimental classes. In contrast, the control class of the analysis results obtained a maximum value of $\left|F_{T}-F_{S}\right|=0.11$. Then converted to KS table price with $\mathrm{df}=30$ and significance level $5 \%$, so that obtained the price of $\mathrm{KS}_{\text {table }}=0.24$. Because the maximum value of $\left|\mathrm{F}_{\mathrm{T}}-\mathrm{F}_{\mathrm{S}}\right|=0.11<\mathrm{KS}_{\text {table }}=0.24$ then $\mathrm{H}_{0}$ received (failed to reject). This means the distribution of the science knowledge competency data of normally distributed control classes.

Furthermore, variance homogeneity tests were conducted against variance between the experimental class and the control class. A homogeneity test was performed to determine whether or not the homogeneous variance of data from the sample group will be analyzed. Variance homogeneity test using F-test formula. The calculated $\mathrm{F}$ price condition obtained compared to the table $\mathrm{F}$ price at a significance level of 5\% with a degree of freedom $(\mathrm{df})=\mathrm{n}-1$. Based on students' science knowledge's homogeneity test data in experimental class and control class obtained, $\mathrm{F}_{\text {count }}=1.37$. The value was then converted at $\mathrm{F}_{\text {table }}=1.84$ with $\mathrm{df}=32$ and 30 . Because $\mathrm{F}_{\text {count }}=1.37<\mathrm{F}_{\text {table }}=1.84$, then it can be said that the science knowledge competency data experimental class and control class had a homogeneous variance

The hypothesis test can be continued using t-test analysis with polled variance formula because the post-test data competency of students' science knowledge was distributed normally and homogeneously. The hypothesis test was conducted at the level of significance $5 \%$ with the rule of hypothesis formula if $t_{\text {calculate }}>t_{\text {table }}$ then $\mathrm{H}_{0}$ is rejected and $\mathrm{H}_{\mathrm{a}}$ is accepted. Conversely, if $\mathrm{t}_{\text {count }}<\mathrm{t}_{\text {table, then }} \mathrm{H}_{0}$ is accepted and $\mathrm{H}_{\mathrm{a}}$ is rejected. The results of the hypothetical test are presented on Table 1.

Table 1. The Result of T-Test Calculation

\begin{tabular}{cccccccc}
\hline Sample & $\mathbf{N}$ & $\mathbf{D f}$ & Mean & $\mathbf{S}^{\mathbf{2}}$ & $\mathbf{t}_{\text {count }}$ & table & Conclusion \\
\hline Experiment Class & 33 & \multirow{2}{*}{62} & 82,42 & 70,81 & \multirow{2}{*}{3,831} & \multirow{2}{*}{2,000} & \multirow{2}{*}{$\mathrm{H}_{0}$ rejected } \\
Control Class & 31 & & 74,90 & 51,69 & & \\
\hline
\end{tabular}


From the results of the test analysis $t$ obtained $t_{\text {count }}=3,831$. The price is then compared with the price of $t_{\text {table }}$ with $\mathrm{df}=(33+31)-2=62$ and the level of significance $5 \%$ so that obtained the price of table $\mathrm{t}=2,000$, because $\mathrm{t}_{\text {count }}=3,831>\mathrm{t}_{\text {table }}=2,000$ Then $\mathrm{H}_{0}$ is rejected. Conclusively, there was a significant difference in the competence of science knowledge between groups of students who are taught using contextual teaching and learning approaches assisted by the school environment media and groups of students who are taught using conventional learning in grade IV students of SD Cluster Lt. Col. I Gusti Ngurah Rai North Denpasar School Year 2019/2020.

\section{Discussion}

From the results of the calculation of data analysis obtained, the experimental group's average value was 82.42 greater than the average value of the experimental group is 74.90 . Thus, the school environment media's contextual teaching and learning approach affect the competence of science knowledge of grade IV students of SD Cluster Lt. Col. I Gusti Ngurah Rai North Denpasar School Year 2019/2020. This is because there are different treatments given mainly in the learning steps. In the experimental group given contextual teaching and learning treatment assisted by the school, environment media contained contextual learning elements that make students actively find their learning activities more practice than theory to learn longer remembered. The components applied in contextual teaching and learning approach are (1) Constructivism, (2) Questioning, (3) Finding, (4) Learning Society, (5) Modeling, (6) Reflection, (7) Actual Assessment. While different learning was given to the control group, whose learning was done only one way or teacher centre. The students were more instilled about the theories that exist in the book instead of being invited to practice so that students feel bored and the media used is only limited.

Based on the presentation, the school environment media's contextual teaching and learning approach can increase the competence of students' science knowledge. Because it provides facilities for students' learning activities in collecting works by searching, processing and finding concrete experiences through a collection of works, students can assess for themselves the development of learning skills through work and efforts that have been done.

Contextual Teaching and Learning as a learning approach concentrates on sharing meaningful and actual experiences with students through activities connecting learning activities in the classroom to the outside environment around the classroom (Yerizon et al., 2020). The opinion of CTL also supports the opinionoriented towards students learning to link between the material studied and the daily activities of students by implying seven main components, namely constructivist, wonder, get information, discussion, demonstration, evaluation. Need to know that CTL can also increase students' knowledge fully in the sense that students are active and independent in finding learning materials by sending and absorbing knowledge through group discussions. The learning process occurred smoothly because it was given a hands-on learning experience such as in the real world so that learning becomes meaningful and impressed long in the student's memory and accelerate students understand of the content of the material with experience in learning. One of the most efficient outside environments to help students provide a direct learning experience is the school environment, which school environment was the closest environment for students in doing daily activities. The environment includes all elements of any kind in the world that can affect human behaviour (Idrus \& Novia, 2018; Julianti et al., 2018; Marini \& Hamidah, 2014). Also supported by (Istialina, 2016), utilizing the learning environment will realize a different learning nuance from the first.

This study's results were reinforced by the conclusion presented by (Dewi et al., 2018) with the title "Influence of Portfolio Assessment-Based CTL on Knowledge Competency of IPA Class V SD Cluster I Gusti Ngurah Rai South Denpasar School Year 20117/2018. Similarly, the research was conducted by (Polih et al., 2013) with the title "Influence of Process Skills Approach by Utilizing School Environment on The Learning Outcomes of Grade-IV Students of SDN GUGUS 6 MENGWI School Year 2012/2013. Conclusively, the use of contextual teaching and learning approach assisted by the school environment media affects the competence of science knowledge of grade IV students of SD Gugus Letkol I Gusti Ngurah Rai Denpasar Utara School Year $2019 / 2020$.

\section{Conclusion}

A conclusion can be drawn by the result of data analysis and discussion that there was an influence of contextual teaching and learning approach assisted by the school environment media on the competence of science knowledge in grade IV students of SD Gugus Letkol I Gusti Ngurah Rai Denpasar Utara School Year $2019 / 2020$. Based on the conclusions that have been presented, the suggestions that can be submitted were as follows. To teachers, to be more creative in designing fun and innovative learning activities for students by using contextual teaching and learning approaches assisted by the school environment media to the competence of 
science knowledge to improve the quality of the learning process and results. To the Principal, to be a guideline for schools and support learning resources for teachers to create the quality and quality of learning in elementary schools. To other researchers, to be used as a reference to carry out further research or find innovations in learning activities meaningful to students.

\section{References}

Agustino, I. K., Manuaba, I. B. S., \& Sujana, I. W. (2016). Pengaruh Model Pembelajaran Inkuiri Berbasis Penilaian Kinerja Terhadap Kompotensi Pengetahuan IPA Siswa kelas IV Gugus IX Abiansemal Kecamatan Abiansemal Tahun pelajaran 2016/2017. MIMBAR PGSD, 1(1), 1-10. https://doi.org/http://dx.doi.org/10.23887/jjpgsd.v6i3.21093

Anjani, L. P. A., Putra, D. K. N. S., \& Ardana, I. K. (2020). Pengaruh Model Pembelajaran Group Investigation Berbantuan Media Semi Konkret Terhadap Kompetensi Pengetahuan IPA Siswa SD. Journal for Lesson and Learning Studies, 3(2), 230-237.

Dewi, D. A. P. H., Darsana, I. W., \& Manuaba, I. . S. (2018). Pengaruh Pendekatan Contextual Teaching and Learning Berbasis Penilaian Portofolio Terhadap Kompetensi Pengetahuan IPA. Journal for Lesson and Learning Studies, 1(3). https://doi.org/10.23887/jlls.v1i3.15387

Effendi-Hasibuan, M. H., Fuldiaratman, Dewi, F., Sulistiyo, U., \& Hindarti, S. (2020). Jigsaw learning strategy in a diverse science-classroom setting: Feasibility, challenges, and adjustment. Cakrawala Pendidikan, 39(3), 733-745. https://doi.org/10.21831/cp.v39i3.30634

Idrus, A., \& Novia, Y. (2018). Pelaksanaan Nilai Peduli Lingkungan Di Sekolah Dasar. Jurnal Gentala Pendidikan Dasar, 3(2), 203-219. https://doi.org/10.22437/gentala.v3i2.6757

Istialina. (2016). Pemanfaatan lingkungan sebagai sumber belajar pada subtema hewan dan tumbuhan di lingkungan rumahku kelas IV SD Negeri 3 Jeumpa Kabupaten Bireuen. Jurnal Ilmiah Mahasiswa Prodi $P G S D, 1(1), 59-68$.

Julianti, R., Drs. H. M Nasirun, M. P., \& Wembrayarli, S.Pd., M. S. (2018). Pelaksanaan PHBS di Lingkungan Sekolah. Ilmiah Potensia, 3(2), 11-17. https://doi.org/https://doi.org/10.33369/jip.3.2.76-82

Juniasih, N. W., Jampel, I. N., \& Setuti, N. M. (2013). Pengaruh Model Pembelajaran Think Talk Write (Ttw) Berbantuan Media Konkret terhadap Hasil Belajar IPA Siswa Kelas IV SD. Jurnal Mimbar PGSD Undiksha.

Kasanah, S. A., Damayani, A. T., \& Rofian, R. (2019). Keefektifan Model Pembelajaran Role Playing Berbantuan Media Multiply Cards terhadap Hasil Belajar Siswa. Jurnal Ilmiah Sekolah Dasar, 3(4), 519-526. https://doi.org/10.23887/jisd.v3i4.22308

Marini, C. K., \& Hamidah, S. (2014). Pengaruh self-efficacy, lingkungan keluarga, dan lingkungan sekolah terhadap minat berwirausaha siswa SMK jasa boga. Jurnal Pendidikan Vokasi, 4(2), 195-207. https://doi.org/10.21831/jpv.v4i2.2545

Oviyana, I. W., Wirya, I. N., \& Sudarma, I. K. (2015). Pengaruh Model Pembelajaran Kooperatif Tipe Jigsaw II Terhadap Hasil Belajar IPA Siswa Kelas VI SD. MIMBAR PGSD Undiksha, 3(1), 124768.

Pane, A., \& Dasopang, M. D. (2017). Belajar dan Pembelajaran. Fitrah, 03(2), 333-352.

Polih, N. K. S., Suardika, I. W. R., \& Putra, D. K. N. S. (2013). Pengaruh Pendekatan Keterampilan Proses Dengan Memanfaatkan Lingkungan Sekolah Terhadap Hasil Belajar Ipa Siswa Kelas Iv Sdn Gugus 6 Mengwi. MIMBAR PGSD Undiksha, 4(2), 1-10.

Putri, N. P. L. K., Kusmariyatni, N., \& Murda, I. N. (2018). Pengaruh Model Pembelajaran Inkuiri Terbimbing Berbantuan Media Audio-Visual Terhadap Hasil Belajar IPA. Mimbar PGSD, 6(3), 153-160. https://doi.org/http://dx.doi.org/10.23887/jjpgsd.v6i3.21093

Shoimin, A. (2014). 68 Model Pembelajaran Inovatif dalam Kurikulum 2013. Ar-Ruzz Media.

Suarnaya, K. D., Dibia, I. K., \& Suarjana, M. (2015). Pengaruh Model Pembelajaran Heuristik-V Berbantuan Media Peta Konsep Terhadap Hasil Belajar IPA. E-Journal PGSD Universitas Pendidikan Ganesha, 2(1). 
Sugiyono. (2012). Metode Penelitian Pendidikan (Pendekatan Kuantitatif, Kualitatif dan R\&D. Alfabeta.

Trianto. (2010). Model Pembelajaran Terpadu. Bumi Aksara.

Widya, N. L. R., Suara, I. M., \& Putra, D. K. N. S. (2015). Pengaruh Model Pembelajaran ARCS Terhadap Hasil Belajar IPA Siswa Kelas VI SDN 11 Sesetan Tahun Pelajaran 2014/2015. E-Journal PGSD Universitas Pendidikan Ganesha, 3(1).

Yerizon, Y., Putri, Y. U., Musdi, E., \& Permana, D. (2020). Efektivitas Perangkat Pembelajaran Matematika Berbasis Pendekatan Contextual Teaching and Learning Terhadap Kemampuan Komunikasi Matematis. AKSIOMA: Jurnal Program Studi Pendidikan Matematika, 9(1), 205. https://doi.org/10.24127/ajpm.v9i1.2305

Yuliana, I. K. M., Dibia, K., \& Riastini3, P. N. (2015). Penerapan Pembelajaran Terpadu Tipe Connected Untuk Meningkatkan Hasil Belajar IPA Kelas VI SD Panji Anom. E-Journal PGSD Universitas Pendidikan Ganesha. 